\title{
Are the effects of an invasive crayfish on lake littoral macroinvertebrate communities consistent over time?
}

\author{
T.J. Ruokonen`, F. Ercoli and H. Hämäläinen \\ University of Jyväskylä, Department of Biological and Environmental Science, P.O. Box 35, 40014, Finland
}

Received February 9, 2016 - Revised June 14, 2016 - Accepted June 15, 2016

\begin{abstract}
Management of invasive species requires assessment of their effects on recipient ecosystems. However, impact assessment of invasive species commonly lacks a long-term perspective which can potentially lead to false conclusions. We examined the effects of the invasive signal crayfish (Pacifastacus leniusculus Dana) on the stony littoral macroinvertebrate communities of a large boreal lake and assessed the extent to which the patterns observed in previous short-term studies were stable over time. We used temporal macroinvertebrate data collected in five consecutive years from a site with a well-established crayfish population, a site with no crayfish and a site where crayfish had been recently introduced. Our results revealed that signal crayfish had temporally rather consistent negative effects on the benthic macroinvertebrate assemblages but that the effects might be limited to certain taxa, in particular Gastropoda and Coleoptera. We also observed increases in Gastropoda density and taxa richness following a decline in crayfish density, indicating that the recovery of invertebrate assemblages might be fast. Hence, negative effects on benthic macroinvertebrates can likely be minimized by effective control of the signal crayfish population.
\end{abstract}

\begin{abstract}
Key-words: crayfish / invasive species / lake / littoral community / macroinvertebrates
Résumé - Les effets d'une écrevisse invasive sur les communautés de macroinvertébrés littoraux d'un lac sontelles stables au fil du temps?. La gestion des espèces envahissantes exige une évaluation de leurs effets sur les écosystèmes récepteurs. Toutefois, l'évaluation de l'impact des espèces envahissantes manque souvent d'une perspective à long terme qui peut potentiellement conduire à des conclusions erronées. Nous avons examiné les effets de l'écrevisse signal invasive (Pacifastacus leniusculus Dana) sur les communautés de macroinvertébrés d'un littoral pierreux d'un grand lac boréal et évalué dans quelle mesure les tendances observées dans les études précédentes à court terme ont été stables au fil du temps. Nous avons utilisé les données temporelles de macroinvertébrés recueillies pendant cinq années consécutives d'un site avec une population d'écrevisses bien établie, d'un site sans écrevisses et d'un site où les écrevisses avaient été introduites récemment. Nos résultats ont révélé que les écrevisses signal ont eu des effets négatifs temporellement plutôt stables sur les assemblages de macroinvertébrés benthiques, mais que les effets pourraient être limités à certains taxons, notamment gastéropodes et coléoptères. Nous avons également observé une augmentation de densité des gastéropodes et de richesse en taxons suite à une baisse de la densité des écrevisses, ce qui indique que la récupération des assemblages d'invertébrés pourrait être rapide. Par conséquent, les effets négatifs sur les macroinvertébrés benthiques peuvent probablement être minimisés par un contrôle efficace de la population d'écrevisses signal.
\end{abstract}

Mots-clés : écrevisses / espèces envahissantes / lac / communauté littorale / macroinvertébrés

\section{Introduction}

Quantifying the effects of invasive species and recognising the most harmful species is essential for effective management of biological invasions (Davis, 2009). Experimental studies, and meta-analyses of their results, can help to identify potentially harmful invasive species and to reveal underlying mechanisms in the species invasions (e.g. Thomsen et al., 2011). However, conclusions drawn from such studies at small spatial and temporal scales necessarily have substantial limitations. For example, a lack of temporal context, as is common in studies of the effects of invasive species, can lead to uncertainties in conclusions (Strayer et al., 2006). Invasive species often exhibit dramatic temporal changes in population size (Simberloff and Gibbons, 2004; Sandström et al., 2014) which could result in variable, and often unpredictable, influences on other biota which could be identified differently in shortterm and long-term studies (Strayer et al., 2006; Kelly et al., 2013). Moreover, time lags, which are typical in species invasion processes (Crooks, 2005), could mask effects and also lead to biased conclusions. Thus empirical studies at more realistic scales are also needed.

\footnotetext{
^ Corresponding author: timo.j.ruokonen@jyu.fi
} 
Even though it is evident that temporal context should be included in studies of species invasions, comparisons of results from short-term studies with empirical data collected over multiple years are rare (Strayer et al., 2006; Thomaz et al., 2012). Due to the often cryptic spread and establishment of non-native species, and the limited availability of long-term monitoring datasets, establishing field studies that include data prior to invasions is difficult. Hence most empirical studies have used a space-for-time substitution approach whereby invaded sites are compared with non-invaded sites, with the underlying assumption that temporal and spatial variations are equivalent (Pickett, 1989; Thomaz et al., 2012). That design certainly has limitations; for example, systematic differences in environmental features between invaded and non-invaded areas might be the actual cause of the differences which are interpreted as effects of the non-native species (Thomaz et al., 2012). Therefore Thomaz et al. (2012) and Dornelas et al. (2013) suggested that a time approach with pre- and postinvasion data from the same area should be used together with a space-for-time design for more reliable assessment of effects. However, in the absence of pre-invasion data, this is not possible. In such cases temporally replicated post invasion studies to assess consistency of patterns could help to justify conclusions drawn from spatial studies.

The impacts of non-native crayfish on freshwater native biota have been increasingly investigated (Lodge et al., 2012; Twardochleb et al., 2013). Studies at various temporal and spatial scales in experimental set-ups, streams and lakes have shown that non-native crayfish can have direct and indirect detrimental effects on benthic macroinvertebrate abundance and species richness, and on snails (Gastropoda) in particular (Nyström, 1999; Twardochleb et al., 2013; Ruokonen et al., 2014; Ercoli et al., 2015). However, few studies (Wilson et al., 2004; McCarthy et al., 2006; Kreps et al., 2012; Hansen et al., 2013; Mathers et al., 2016) have examined the effects of invasive crayfish using data collected over multiple years. We therefore examined the effects of invasive signal crayfish (Pacifastacus leniusculus Dana) on the stony littoral benthic macroinvertebrate communities of a large boreal lake, and assessed the extent to which the patterns previously observed in short-term space-for-time studies in the same lake (Bjurström et al., 2010; Ruokonen et al., 2014) were stable over time. We used temporal data collected in 5 consecutive years from a site with a well-established crayfish population, a site with no crayfish and a site where crayfish had been recently introduced. We also included in our analysis environmental variables known to shape the lake littoral communities, to help distinguish the importance of invader effects from annual variability attributable to other influences.

Our previous spatial studies in the same area suggested that the presence of crayfish affects macroinvertebrate assemblage composition and decreases macroinvertebrate taxon richness, and especially decreases snail density and taxon richness. Hence, we expected that assemblage composition and taxon richness should differ between the crayfish site and non-crayfish site consistently over the years. We also studied the short-term dynamics of the littoral benthic macroinvertebrate community, and any potential time lag in its response, following introduction of a new signal crayfish population.

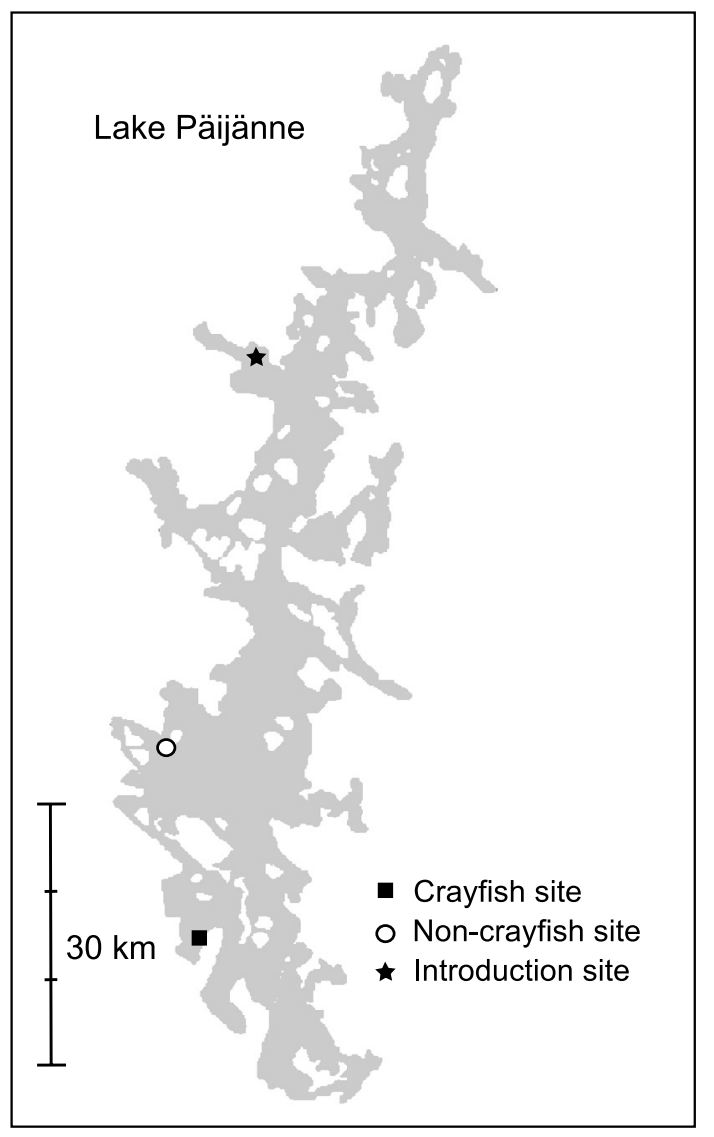

Fig. 1. Study sites in Lake Päijänne. The established crayfish site is indicated with a solid black square, the non-crayfish site with an open circle, and the site where crayfish had been recently introduced with an asterisk.

We expected that following the crayfish introduction snail density and species richness should decrease and the species composition of the benthic macroinvertebrate assemblage should gradually shift towards that of the site with a long-established crayfish population.

\section{Material and methods}

\subsection{Study sites}

The study was conducted in 2007-2011 at Lake Päijänne, the second largest lake in Finland (Figure 1). From the sites originally selected for our previous studies (Bjurström et al., 2010; Ruokonen et al., 2014), we chose one established crayfish site at Padasjoki $\left(61^{\circ} 20^{\prime} \mathrm{N}, 25^{\circ} 21^{\prime} \mathrm{E}\right)$ and one non-crayfish site at Kuhmoinen $\left(61^{\circ} 31^{\prime} \mathrm{N}, 25^{\circ} 15^{\prime} \mathrm{E}\right)$ for a long-term followup. Signal crayfish were introduced to the Padasjoki study site in 1990, and the population reproduces naturally and supports an important recreational and commercial fishery in the area. The sampled crayfish site is located in the most productive signal crayfish area in Finland representing a regionally high crayfish density (Erkamo et al., 2010; Ruokonen et al., 2014; Ercoli et al., 2015). We selected one additional site at Saalahti $\left(61^{\circ} 55^{\prime} \mathrm{N}, 25^{\circ} 26^{\prime} \mathrm{E}\right)$ where signal crayfish had been 
recently introduced. This site was sampled once for macroinvertebrates before the first crayfish introduction in September 2007 (Bjurström et al., 2010), when 800 signal crayfish juveniles $(1+$ age, mean length $38 \mathrm{~mm}$ ) were released to the study site by the local water owners. Similar crayfish introductions (800 juveniles per year) continued during the three following years (2008-2010). The crayfish were introduced to two locations along a $100 \mathrm{~m}$ stretch of stony shore. This intensity of introduction usually leads to establishment of signal crayfish population in Finnish lakes (Erkamo et al., 2010).

\subsection{Environmental factors}

All study sites were exposed shores without macrophytes and with hard substrata consisting of cobbles and boulders. The study sites had comparable key habitat features (substratum particle size, slope; Bjurström et al., 2010; Ruokonen et al., 2014), and water quality (Hertta environmental database, Finnish Environment Institute), all of which are known to shape the structure of littoral communities (Tolonen et al., 2001).

Annual variation in environmental factors might alter lake littoral community composition and should be taken into account when studying long-term effects of invasive species (Strayer et al., 2006). For example, timing of macroinvertebrate life-cycles and activity of ectothermic crayfish (e.g. feeding rates and timing of moulting) are likely to vary greatly among years along with variable ambient water temperatures, and might modify the manifestation of crayfish effects. Therefore, in the analysis we used mean water temperature of the warmest month, July, for each year from the closest automatic sampling station (Päijätsalo, $61^{\circ} 28^{\prime} \mathrm{N}, 25^{\circ} 33^{\prime} \mathrm{E}$, Finnish Environment Institute) to control for the potential effects of thermal variability among study years.

The water level of Lake Päijänne is slightly regulated for flood protection and hydro-power production. During the study period, annual variation between maximum and minimum water level averaged $54 \mathrm{~cm}$ (Hertta database, Finnish Environment Institute). This small amplitude of water-level regulation is not likely to significantly affect the littoral communities of boreal lakes (Aroviita and Hämäläinen, 2008; Sutela et al., 2011). Nevertheless, we obtained water level (m.a.s.l.) data for Lake Päijänne (Kalkkistenkoski, $61^{\circ} 16^{\prime} \mathrm{N}$, $25^{\circ} 35^{\prime} \mathrm{E}$ ) from the Hertta-database (Finnish Environment Institute), and used the mean water level in July and lowest water level during winter in the analysis as candidate predictors of community variability as those have found to explain littoral invertebrate community variability among regulated lakes (Aroviita and Hämäläinen, 2008).

During the past decades (1960s to 1980s) northern Lake Päijänne suffered from heavy anthropogenic point-source pollution. However, as a result of major reductions in effluent loading, water quality is now substantially improved and differences in water quality $(\mathrm{pH}$, total phosphorus concentration, chlorophyll-a) potentially affecting littoral invertebrate communities are currently negligible between the studied subbasins. The sampled crayfish and non-crayfish sites are in the southern part of the lake with a long-term (2000-2011) TP range of $6-11 \mu \mathrm{g} \cdot \mathrm{g} \cdot \mathrm{L}^{-1}$ similar to that in the northern area $\left(6-13 \mu \mathrm{g} \cdot \mathrm{g} \cdot \mathrm{L}^{-1}\right)$ where the introduction site is. Nevertheless, to control for any possible effect of small spatial and temporal variation of water quality on invertebrate assemblages, total phosphorus content $\left(\mu \mathrm{g} \cdot \mathrm{L}^{-1}\right)$ at $1 \mathrm{~m}$ depth in August each year was obtained from the nearest water quality sampling station (distance from 3 to $6 \mathrm{~km}$ ) (Hertta database, Finnish Environmental centre) for the analysis.

\subsection{Field sampling}

At each study site the macroinvertebrate sampling and crayfish trapping were temporally matched across years. The Padasjoki crayfish site and the Kuhmoinen non-crayfish site were sampled at the beginning of August on consecutive days and the Saalahti introduction site three weeks later every year.

The study sites were trapped each year for one night to estimate crayfish abundance (crayfish/trap/night) and to confirm the continued absence of crayfish at the non-crayfish site. At each site, 25 cylindrical foldable Evo-traps of mesh size $15 \mathrm{~mm}$ (Westman et al., 1979) baited with fresh fish (Rutilus rutilus) flesh were set in the 1-3 $\mathrm{m}$ depth zone along the shore at $5 \mathrm{~m}$ intervals during the evening and collected the next morning, following the standard method used in Finland (e.g. Erkamo et al., 2010). The crayfish traps are size-selective and provide an estimate of abundance of adult crayfish (>30 mm in carapace length). At the non-crayfish site, the absence of crayfish was further verified by a scuba diver during macroinvertebrate sampling.

Benthic macroinvertebrates were sampled using a system powered by a water pump operated from a boat (Tolonen et al., 2001). A scuba diver cleaned a framed area of bottom $\left(0.25 \mathrm{~m}^{2}\right)$ sucking up the sample to a sieve of mesh size $0.5 \mathrm{~mm}$ (see Ruokonen et al., 2014 for a more detailed description). At all sites, three random replicate samples were taken each year from $1 \mathrm{~m}$ depth and preserved in $70 \%$ ethanol. Macroinvertebrates were sorted from the samples in the laboratory, identified to the lowest feasible taxonomic level (mostly genus or species) and counted.

\subsection{Statistical analyses}

General linear models were used to compare the abundance (density, individuals $\mathrm{m}^{-2}$ ) and species richness (number of taxa) of all macroinvertebrates and Gastropoda between the three study sites with different crayfish status (crayfish, noncrayfish and recently introduced) and among study years. In addition, the abundances of other prevalent benthic macroinvertebrate groups (Bivalvia, Coleoptera, Crustacea, Diptera, Ephemeroptera, Isopoda, Oligochaeta, and Trichoptera) were similarly tested among sites and years. When only significant main effects were observed, Tukey post hoc comparisons were conducted separately between sites and years (package multcomp in R). When the interaction effect between sites and year was significant, a post hoc analysis of interactions was conducted for the adjusted mean of the response for the corresponding interaction of factors using the package phia in R. For the sake of clarity, significant main effects and interactions which were apparently connected to the presence 


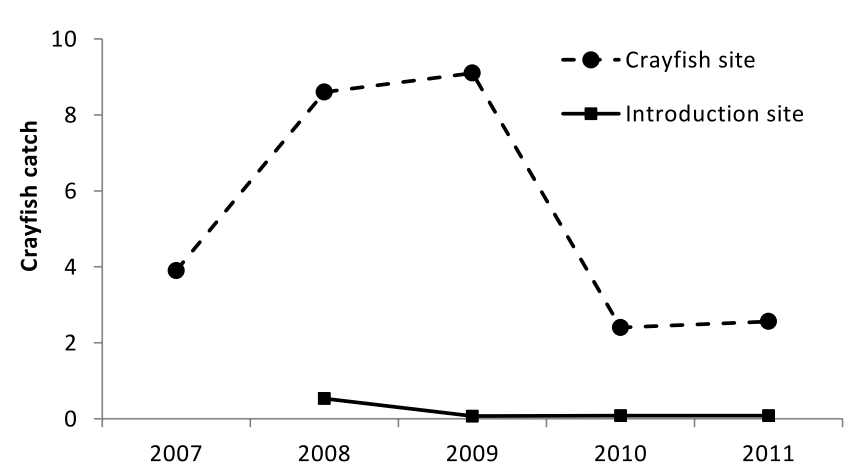

Fig. 2. Crayfish catches (crayfish/trap/night) at the crayfish and recent introduction sites in Lake Päijänne from 2007 to 2011.

of crayfish are presented in the text. Results for other taxa are presented in Supplementary material. Residual plots were visually inspected to check any deviation from homoscedasticity or normality. Due to skewedness of residuals, Gastropoda and Coleoptera densities were log-transformed prior to the analyses.

Spatial and temporal patterns in the benthic macroinvertebrate assemblage composition were assessed with non-metric multidimensional scaling (NMDS) ordination, using BrayCurtis distance measure and transformed $[\log (x+1)]$ data. To evaluate the effect of environmental factors on assemblage composition, NMDS axes were correlated with a secondary matrix containing environmental data (mean water temperature in July, mean water level on July, lowest water level during winter drawdown, total phosphorus). Differences in assemblage composition between crayfish, non-crayfish and recently introduced sites were tested with a blocked Multi-Response Permutation Procedure using sampling year as blocking factor (MRPP, based on Euclidian distances).

Statistical analyses were performed with R 3.0.3 (R Core Team, 2014) using vegan-package for NMDS-analysis. MRPP was performed with PC-ORD 5.0. software (MjMSoftware, Gleneden Beach, OR, U.S.A.).

\section{Results}

The mean catch at the Padasjoki crayfish site was 5.3 crayfish per trap night during the follow-up period. However, the catch varied greatly among years being highest in 2009 (9.1) and lowest in 2010 (2.4) (Figure 2). The mean catch at the crayfish introduction site was only 0.19 crayfish per trap, and remained low $(0.1-0.5)$ through the whole period (Figure 2). No crayfish were observed at the non-crayfish site or at the introduction site before the crayfish introduction.

The total macroinvertebrate density was significantly different between study sites and years with an interaction (Table 1). However, the density was similar at the crayfish and non-crayfish sites ( $p=0.248, P=0.935)$ throughout the study years (Figure $3 \mathrm{~A}$ ). The total macroinvertebrate density was higher at the recent introduction site than at the crayfish and non-crayfish sites (Figure 3A) but only in 2008 and 2009 (both $p<0.001$ ).
The mean Gastropoda density differed between study sites $(p<0.001)$, and between years $(p<0.001)$, and there was an interaction between site and year $(p<0.001)$ indicating that density differences across study sites varied among years (Table 1, Figure 3B). Post-hoc analysis of interactions showed that Gastropoda density differed between sites with different crayfish status in every year (all $p<0.001$ ) except 2011 ( $p=0.755)$ (Figure 3B), being lower at the crayfish site than at the non-crayfish and introduction sites in 2008-2010 (all $p<0.001$ ). In addition, Gastropoda density in 2008 and 2009 at the recent introduction site was higher than at the noncrayfish site (Figure 3B).

The mean Coleoptera density was consistently lower at the crayfish site than at the non-crayfish site $(p<0.001)$ and the recent introduction site ( $p=0.007)$ (Figure 3D). Coleoptera density did not significantly vary in time and there was no interaction between site and year (Table 1).

The mean densities of other macroinvertebrate taxa (Bivalvia, Crustacea, Diptera, Ephemeroptera, Hirunidea, Oligochaeta, and Trichoptera) showed significant differences between study sites with interactions between site and time (Table 1). However, post-hoc analysis of interactions (detailed results presented in Supplementary information) indicated that densities differed sporadically, mainly within the introduction site, and that the variation was not clearly connected to the presence or absence of crayfish (Figure 3 ).

Overall macroinvertebrate taxon richness differed between sites, and between study years (Figure 4, Table 1). Post hoc comparisons suggested significantly fewer taxa at the crayfish site than at the recent introduction site $(p<0.001)$ and the non-crayfish site $(p<0.001)$ (Figure 4A). Taxon richness in 2011 was higher than in $2007(p<0.001)$ and 2009 ( $p=0.016$ ), but there was no significant interaction between site and year (Table 1), suggesting consistent differences in taxon richness between sites during the follow up period.

The mean Gastropoda species richness differed significantly among study sites $(p<0.001)$, and also varied between study years $(p<0.001)$, with an interaction between site and year $(p<0.001)$ (Table 1, Figure 4B). Post-hoc comparisons of interactions indicated that Gastropoda richness at the noncrayfish and recent introduction sites was higher than at the crayfish site during 2007-2010 (all $p$-values $<0.001$ ). However, in 2011 the difference was not so evident ( $p=0.076$ ).

A three-dimensional NMDS solution (Final stress $=0.08$ ) best described the variation in benthic macroinvertebrate assemblages, and the three sites were clearly clustered according to their crayfish status along the axis 1 in particular (Figures $5 \mathrm{~A}$ and $5 \mathrm{~B})$. Mean water temperature in July $(r=0.66)$ and the minimum water level during winter $(r=0.65)$ showed a strong correlation with axis 2 (Figures $5 \mathrm{~A}$ and $5 \mathrm{C}$ ), which also seemed to correlate with time. Neither mean water level in July nor total phosphorus concentration correlated significantly with any axis (all $p>0.05$ ). A blocked MRPP supported the NMDS results, indicating significant differences in benthic macroinvertebrate assemblages between the crayfish and non-crayfish sites $(T=-3.11, A=0.21, p=0.015)$, between the crayfish and recent introduction sites $(T=-2.93$, $A=0.19, p=0.015)$, and also between the non-crayfish and recent introduction sites $(T=-2.77, A=0.15, p=0.016)$. 
T.J. Ruokonen et al.: Knowl. Manag. Aquat. Ecosyst. (2016) 417, 31

Table 1. Results of the GLM for the effects of crayfish status and time on macroinvertebrate densities and species richness.

\begin{tabular}{|c|c|c|c|c|}
\hline Response & Factors & d.f. & $\mathbf{F}$ & $\mathbf{P}$ \\
\hline \multirow[t]{3}{*}{ Overall density } & Crayfish status & 2 & 17.09 & $<0.001$ \\
\hline & Year & 4 & 5.10 & 0.003 \\
\hline & Crayfish status * Year-interaction & 8 & 3.61 & 0.005 \\
\hline \multirow[t]{3}{*}{ Gastropoda density } & Crayfish status & 2 & 161.00 & $<0.001$ \\
\hline & Year & 4 & 8.95 & $<0.001$ \\
\hline & Crayfish status * Year-interaction & 8 & 11.85 & $<0.001$ \\
\hline \multirow[t]{3}{*}{ Bivalvia density } & Crayfish status & 2 & 4.42 & 0.021 \\
\hline & Year & 4 & 2.32 & 0.081 \\
\hline & Crayfish status $*$ Year-interaction & 8 & 2.28 & 0.050 \\
\hline \multirow[t]{3}{*}{ Coleoptera density } & Crayfish status & 2 & 30.74 & $<0.001$ \\
\hline & Year & 4 & 2.05 & 0.114 \\
\hline & Crayfish status * Year-interaction & 8 & 1.54 & 0.188 \\
\hline \multirow[t]{3}{*}{ Crustacea density } & Crayfish status & 2 & 13.88 & $<0.001$ \\
\hline & Year & 4 & 10.53 & $<0.001$ \\
\hline & Crayfish status * Year-interaction & 8 & 10.53 & $<0.001$ \\
\hline \multirow[t]{3}{*}{ Diptera density } & Crayfish status & 2 & 2.97 & 0.067 \\
\hline & Year & 4 & 2.39 & 0.074 \\
\hline & Crayfish status * Year-interaction & 8 & 3.50 & 0.006 \\
\hline \multirow[t]{3}{*}{ Ephemeroptera density } & Crayfish status & 2 & 31.08 & $<0.001$ \\
\hline & Year & 4 & 13.95 & $<0.001$ \\
\hline & Crayfish status $*$ Year-interaction & 8 & 10.67 & $<0.001$ \\
\hline \multirow[t]{3}{*}{ Hirunidea density } & Crayfish status & 2 & 16.17 & $<0.001$ \\
\hline & Year & 4 & 18.61 & $<0.001$ \\
\hline & Crayfish status $*$ Year-interaction & 8 & 10.88 & $<0.001$ \\
\hline \multirow[t]{3}{*}{ Oligochaeta density } & Crayfish status & 2 & 7.012 & 0.003 \\
\hline & Year & 4 & 3.111 & 0.030 \\
\hline & Crayfish status * Year-interaction & 8 & 3.347 & 0.007 \\
\hline \multirow[t]{3}{*}{ Trichoptera density } & Crayfish status & 2 & 28.76 & $<0.001$ \\
\hline & Year & 4 & 16.38 & $<0.001$ \\
\hline & Crayfish status $*$ Year-interaction & 8 & 14.36 & $<0.001$ \\
\hline \multirow[t]{3}{*}{ Overall species richness } & Crayfish status & 2 & 17.092 & $<0.001$ \\
\hline & Year & 4 & 4.302 & $<0.001$ \\
\hline & Crayfish status * Year-interaction & 8 & 1.708 & 0.130 \\
\hline \multirow[t]{3}{*}{ Gastropoda species richness } & Crayfish status & 2 & 153.02 & $<0.001$ \\
\hline & Year & 4 & 5.29 & $<0.001$ \\
\hline & Crayfish status $*$ Year-interaction & 8 & 6.22 & $<0.001$ \\
\hline
\end{tabular}

\section{Discussion}

The results of this temporal study were generally consistent with our previous findings from largescale spatially replicated space-for-time studies in Lake Päijänne (Bjurström et al., 2010; Ruokonen et al., 2014) and in other boreal lakes (Ruokonen et al., 2014; Ercoli et al., 2015) The overall mean benthic macroinvertebrate densities were similar at the crayfish and non-crayfish sites throughout the study years 2007-2011, as found previously (Bjurström et al., 2010; Ruokonen et al., 2014). Even though this contrasts with some previous studies (Nyström et al., 1999; Nilsson et al., 2012; Twardochleb et al., 2013), Ercoli et al. (2015) found no differences in littoral benthic macroinvertebrate densities between smaller Finnish lakes with crayfish and without crayfish, suggesting any effect of signal crayfish on overall numerical abundance of littoral benthic macroinvertebrates in boreal lakes is probably weak.

As expected from our previous results (Bjurström et al., 2010; Ruokonen et al., 2014), the overall benthic macroinvertebrate mean species richness at the crayfish site was lower than at the non-crayfish site throughout the study years, except in 2011 when species richness abruptly increased at the crayfish site. Consistent with the previous spatial comparisons, the mean snail density and species richness in most study years were also lower at the crayfish site. However, the density and species richness of snails increased significantly in 2011, together with the overall species richness. Previous studies have shown that benthic macroinvertebrate communities can recover rather quickly after a decline in crayfish population in both lakes (McCarthy et al., 2006) and streams 

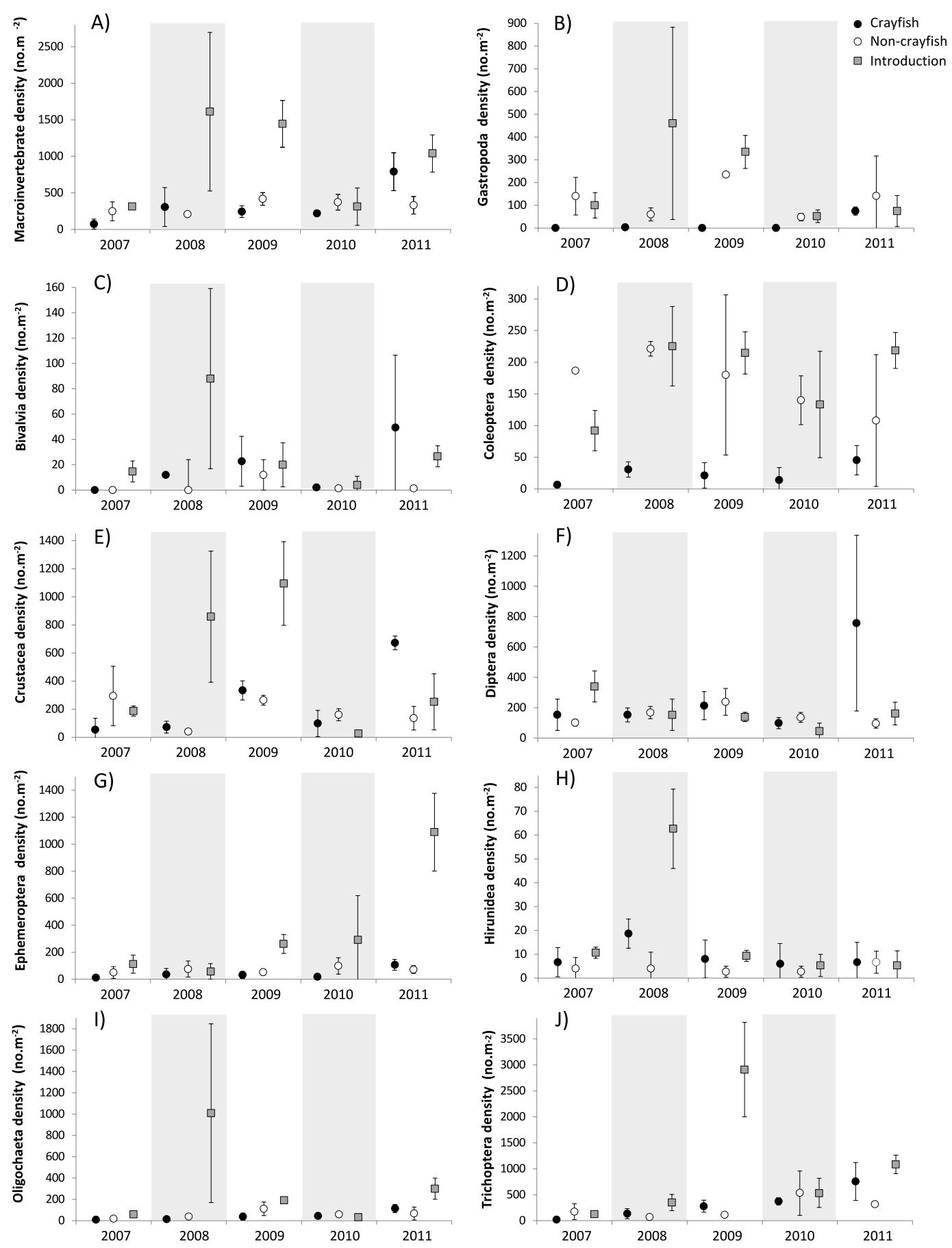

Fig. 3. Macroinvertebrate mean ( \pm S.D.) densities at the crayfish, non-crayfish and recent introduction sites in Lake Päijänne from 2007 to 2011. (A) macroinvertebrate total density, (B) Gastropoda density, (C) Bivalvia density, (D) Coleoptera density, (E) Crustacea density, (F) Diptera density, (G) Ephemeroptera density, (H) Hirunidea density, (I) Oligochaeta density, and (J) Trichoptera density.

(Moorhouse et al., 2014). Hansen et al., (2013) reported a large increase in gastropod densities following a dramatic decline in crayfish abundance. Hence, the abrupt decrease in crayfish abundance in 2010 and the following year, which we presume to be a combination of high trapping pressure and natural variation in recruitment, might explain the increased density and species richness of snails and total taxon richness in 2011 at the crayfish site.
We found that the mean density of Coleoptera, consisting mainly of riffle beetles Oulimnius tuberculatus and Normandia nitens, was lower at the crayfish site than at the other sites through the whole study period, with no signs of change in 2011. In our previous studies, riffle beetles indicated a lack of crayfish (Bjurström et al., 2010; Ruokonen et al., 2014). Guan and Wiles (1998) found that signal crayfish in a British river fed on Coleoptera and, although consumption varied 

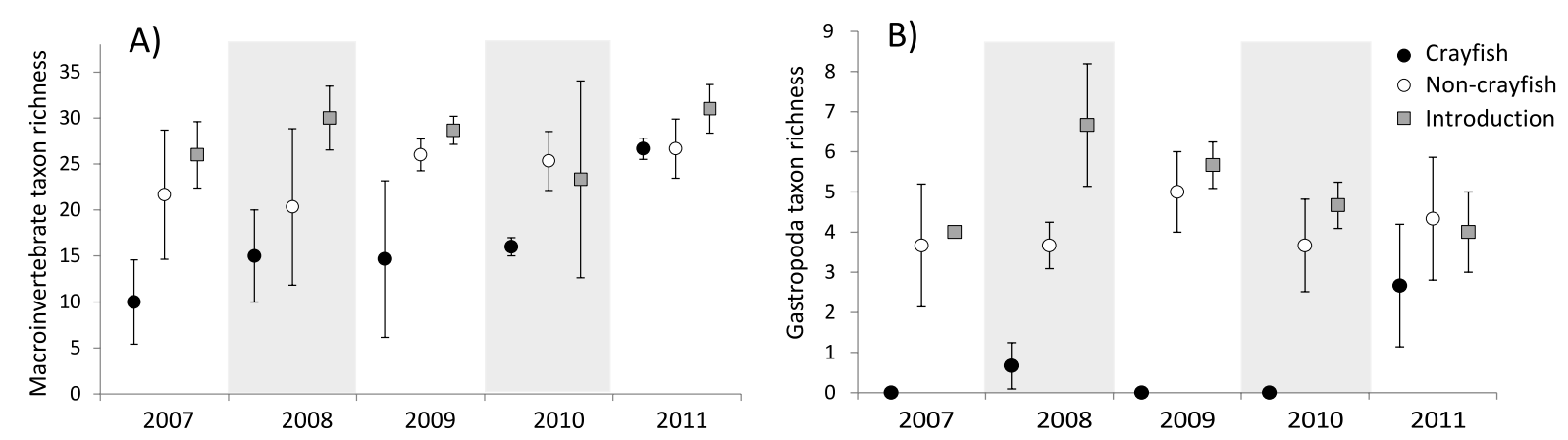

Fig. 4. Macroinvertebrate mean ( \pm S.D.) taxa richness at the crayfish, non-crayfish and recent introduction sites in Lake Päijänne from 2007 to 2011. A) macroinvertebrate total macroinvertebrate total taxon richness, and B) Gastropoda taxon richness.

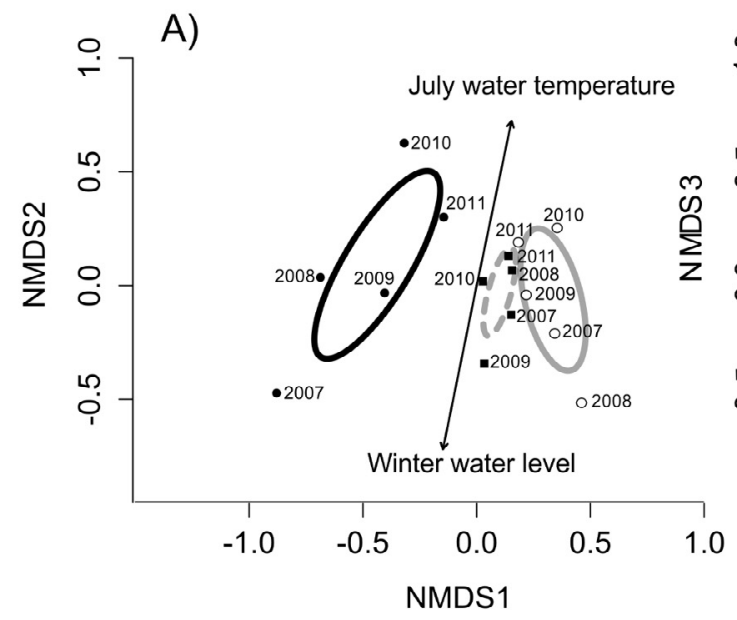

B)

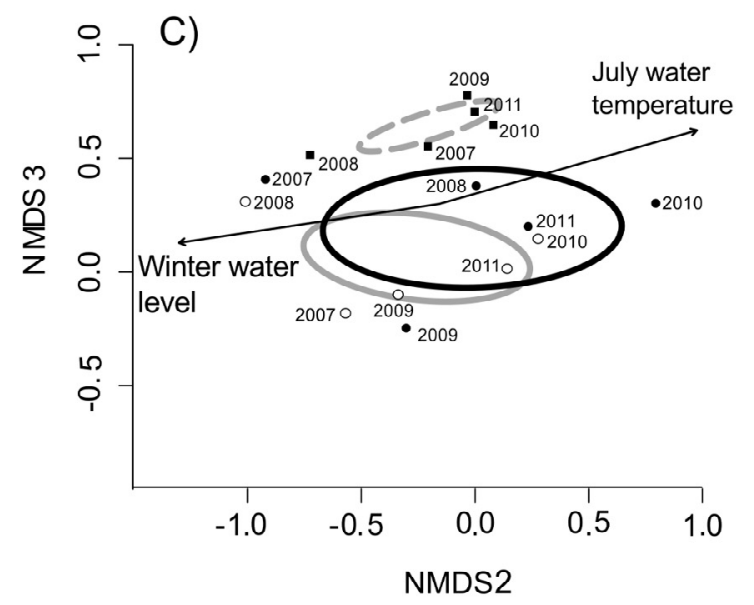

- Crayfish site

- Non-crayfish site

- Introduction site

Fig. 5. Non-metric multidimensional scaling solutions for the crayfish, non-crayfish and recent introduction sites over the study years (2007-2011) in Lake Päijänne. Arrows indicate environmental factors having significant correlations with the solution axes.

with crayfish age and season, the results suggested potential reduction of these taxa by signal crayfish predation. Other studies have shown that riffle beetles are especially vulnerable to disturbances in the aquatic environment (Aroviita and Hämäläinen, 2008; Elliot, 2008). Hence the lower riffle beetle densities at crayfish sites might stem from the vulnerability to predation during the semivoltine life-cycle which is mostly aquatic, in combination with poor colonisation abilities (Aroviita and Hämäläinen, 2008; Elliot, 2008). Riffle beetles have generally limited flying ability, which is thought to be one reason for their rather slow colonisation (Elliot, 2008), and this could be particularly important in lake littoral zones where there is no possibility to drift with flow as in rivers. Although recovery of most macroinvertebrates after disturbance is rather fast (Niemi et al., 1990), Hoffsten (2003) found that Elmidae beetle densities and taxa richness were reduced during harsh conditions in Swedish rivers and their recovery was slow. Therefore it could be expected that signal crayfish would 
cause local extinctions of riffle beetles and recovery might take a long time even after the crayfish population decreases or disappears.

The densities of other abundant macroinvertebrate groups (Bivalvia, Crustacea, Diptera, Ephemeroptera, Hirunidea, Oligochaeta, and Trichoptera) were not consistently related to crayfish presence or absence. Several previous studies have shown that macroinvertebrate groups other than Gastropoda do not commonly respond negatively to the presence of nonnative crayfish, or that responses are highly variable across groups (e.g. Nyström et al., 1999; Wilson et al., 2004; Ruokonen, 2014). We observed some deviating observations, mostly at the recent introduction site, without clear connection to the presence of crayfish. We believe that those observations are most probably related to natural variation and spatial patchiness in abundance across study sites which could not be explained by the measured factors.

Our ordination analysis revealed temporally consistent differences in the benthic macroinvertebrate assemblages across sites with contrasting crayfish status. The results also showed concordant annual variation among the study sites. This variation could be linked to environmental factors, as we found both July water temperature and lowest winter water level correlated significantly with the second axis. However, the grouping according to crayfish status remained evident throughout all study years across the first axis, suggesting that crayfish effects on taxonomic composition are rather stable over time. Notably, in the two last years with reduced crayfish abundance, the macroinvertebrate assemblages at the crayfish site shifted towards those at the sites with no or low crayfish abundance along the first or 'crayfish effect' axis.

Few studies have documented any effects of invasive crayfish on other biota in the early stages of invasion. Wilson et al. (2004) and McCarthy et al. (2006) showed that after rusty crayfish (Orconectes rusticus) invasion, macroinvertebrate species richness and density declined drastically until the crayfish density reached a certain threshold. In our study, the total benthic macroinvertebrate density at the recent introduction site was similar to that at the crayfish and non-crayfish sites before the crayfish introduction, but in contrast to our expectations we detected a clear increase in macroinvertebrate density in the two years following the introduction. This might be related to the disturbance caused by crayfish which led to a change in the structure of the macroinvertebrate community. We also expected that snails, which are the most vulnerable taxa to crayfish predation (Nyström, 1999; Twardochleb et al., 2013), would be affected negatively by the crayfish introduction. However, we found no consistent change in the snail densities or species richness at the introduction site. Similarly, variation in benthic macroinvertebrate assemblage composition was minor throughout the years, and there was no clear shift towards greater resemblance in composition to the crayfish site.

Even though there might be a time lag in the responses, the most likely reason for the unexpected results at the recent introduction site is that the crayfish population simply did not become well-established during the follow-up period. The crayfish density remained very low and previous studies have reported that crayfish effects on macroinvertebrates are density-dependent (Hansen et al., 2013; Ruokonen et al., 2014; Wilson et al., 2004). Our five year follow-up period is rather short, even though an exploitable signal crayfish population (catch/trap/night $>1$ ) in Finnish lakes can develop within five years (Erkamo et al., 2010). However, the success of establishment of new signal crayfish populations varies; Erkamo et al. (2010) reported that $67 \%$ of stockings in Finland were unsuccessful and resulted in only weak populations. In 2009, we observed signs (melanised spots) of severe crayfish plague (Aphanomyces astacii) outbreak in most of the crayfish trapped from the recent introduction site (Ruokonen, unpublished data). We suppose this could be one reason for poor establishment of a signal crayfish population in the area. Recently several collapses of abundant signal crayfish populations related to changes in environment in combination with diseases have been reported in Sweden and Finland (Jussila et al., 2014; Sandström et al., 2014). However, signal crayfish is a rather new species (from 20 to 30 years) in most Finnish water systems and some of the variation is likely related to ongoing invasion process where ecosystem compartments are still seeking a balance, in which case lakes with low signal crayfish densities should become more frequent in the future.

We conclude, that successful introductions of signal crayfish to large boreal lakes cause a temporally persistent decrease in the diversity of benthic macroinvertebrates, and of snails and aquatic beetles in particular, equivalent to that detected in spatial comparisons. On the basis of these results, together with recent findings from small and medium-sized Finnish lakes (Ercoli et al., 2015), we further conclude that effects of signal crayfish on snails and aquatic beetles are rather distinct and predictable in boreal lakes, whereas apparently variable among other macroinvertebrate groups. However, the recovery of invertebrate assemblages might be fast if crayfish densities decrease (Moorhouse et al., 2014), and hence any effects of invasive crayfish can likely be minimized by active control of the crayfish populations.

Acknowledgements. We thank the fisheries shareholder associations at Saalahti, Kuhmoinen and Padasjoki for permission to access their waters. We also thank Kimmo Sivonen, Simo Jalli, Pasi Laulumaa, Marjut Mykrä and Juho Haatanen for their assistance in the field. We also thank Prof. Roger Jones for checking the language. The critical comments of two anonymous reviewers helped to improve the manuscript. The study was financially supported by the Vanhanselkä fisheries shareholder association, the Maj and Tor Nessling Foundation (TJR, FE), and the Crayfish Research Program of the Finnish Game and Fisheries Institute.

\section{References}

Aroviita J. and Hämäläinen H., 2008. The impact of water-level regulation on littoral macroinvertebrate assemblages in boreal lakes. Hydrobiologia, 613, 45-56.

Bjurström L., Ruokonen T.J., Pursiainen M., Jones R.I. and Hämäläinen H., 2010. Impacts of the invasive signal crayfish on littoral macroinvertebrates of large boreal lakes: A pilot study in Lake Päijänne, Finland. Freshw. Cray., 17, 177-182.

Crooks J., 2005. Lag times and exotic species: The ecology and management of biological invasions in slow-motion. Ecoscience, 12, 316-329. 
Davis M.A., 2009. Invasion Biology. Oxford University Press, New York.

Dornelas A., et al., 2013. Quantifying temporal change in biodiversity: challenges and opportunities. Proc. Biol. Sci., 280, 20121931.

Elliot J.M., 2008. The ecology of riffle beetles (Coleoptera: Elmidae). Fresw. Rew., 1, 189-203.

Ercoli F., Ruokonen T.J., Erkamo E., Jones R.I. and Hämäläinen H., 2014. Comparing the effects of introduced signal crayfish and native noble crayfish on the littoral invertebrate communities of boreal lakes. Freshw. Sci., 34, 555-563.

Ercoli F., Ruokonen T.J., Koistinen S., Jones R.I. and Hämäläinen H., 2015. The introduced signal crayfish and native noble crayfish have different effects on sublittoral macroinvertebrate assemblages in boreal lakes. Fresw. Biol., 60, 1688-1698.

Erkamo E., Ruokonen T., Alapassi T., Ruokolainen J., Järvenpää T., Tulonen J. and Kirjavainen J., 2010. Evaluation of crayfish stocking success in Finland. Freshw. Cray., 17, 77-83.

Guan R.Z. and Wiles P.R., 1998. Feeding ecology of the signal crayfish Pacifastacus leniusculus in a British lowland river. Aquaculture, 169, 177-193.

Hansen G.J.A., Hein C.L., Roth B.M., Vander Zanden M.J., Gaeta J.W., Latzka A.W. and Carpenter S.R., 2013. Food web consequences of long-term invasive crayfish control. Can. J. Fish. Aquat. Sci., 70, 1109-1122.

Hoffsten P-O., 2003. Effects of an extraordinarily harsh winter on macroinvertebrates and fish in boreal streams. Arch. Hydrobiol., $157,505-523$.

Jussila J., Makkonen J., Kokko H. and Mäkinen P., 2014. Numerous population crashes of wild signal crayfish (Pacifastacus leniusculus) in Southern Finland. Freshw. Cray., 20, 73-79.

Kelly N.E., Yan N.D., Walseng B. and Hessen D.O. , 2013. Differential short- and long-term effects of an invertebrate predator on zooplankton communities in invaded and native lakes. Diversity and Distributions, 19, 396-410.

Kreps T.A., Baldridge A.K. and Lodge D.M., 2012. The impact of an invasive predator (Orconectes rusticus) on freshwater snail communities: insights on habitat-specific effects from a multilake long-term study. Can. Fish. Aquat. Sci., 69, 1164-1173.

Lodge D.M. et al., 2012. Global Introductions of Crayfishes: Evaluating the Impact of Species Invasions on Ecosystem Services. Annu. Rev. Ecol. Evol. Syst., 43, 449-479.

Mathers K.L., Chadd R.P., Dunbar M.J., Extence C.A., Reeds J., Rice S.P. and Wood P.J., 2016. The long-term effects of invasive signal crayfish (Pacifastacus leniusculus) on instream macroinvertebrate communities. Sci. Total. Environ., 556, 207-218

McCarthy J.M., Hein C.L., Olden J.D. and Vander Zanden M.J., 2006. Coupling long-term studies with meta-analysis to investigate impacts of non-native crayfish on zoobenthic communities. Freshw. Biol., 51, 224-235.

Moorhouse T.P., Poole A.E., Evans L.C., Bradley D.C. and Macdonald D.W., 2014. Intensive removal of signal crayfish (Pacifastacus leniusculus) from rivers increases numbers and taxon richness of macroinvertebrate species. Ecol. Evol., 4, 494-504.

Niemi G.J., DeVore P., Detenbeck N.E., Taylor D., Lima A. and Pastor J., 1990. Overview of case studies on recovery of aquatic systems from disturbance. Environ. Manage., 14, 571-587.
Nilsson E., Solomon C.T., Wilson K.A., Willis T.V., Larget B. and Vander Zanden M.J., 2012. Effects of an invasive crayfish on trophic relationships in north-temperate lake food webs. Freshw. Biol. 57, 10-23.

Nyström P., 1999. Ecological impact of introduced and native crayfish on freshwater communities: European perspectives. In: Gherardi F. and D.M. Holdich (eds.), Crayfish in Europe as alien species - How to make the best of bad situation? A.A. Balkema, Rotterdam.

Nyström P., Brönmark C. and Graneli W., 1999. Influence of an exotic and a native crayfish species on a littoral benthic community. Oikos, 85, 545-553.

Nyström P., Svensson O., Lardner B., Brönmark C. and Graneli W., 2001. The influence of multiple introduced predators on a littoral pond community. Ecology, 82, 1023-1039.

Pickett S.T.A., 1989. Space-for-time substitution as an alternative to long term studies. In: Likens G.E. (ed.), Long-Term Studies in Ecology: Approaches and Alternatives, SpringerVerlag, New York.

R Core Team, 2015 R: A language and environment for statistical computing. R Foundation for Statistical Computing, Vienna, Austria. Available at: https://www.R-project.org/.

Ruokonen T.J., Karjalainen J. and Hämäläinen H., 2014. Effects of an invasive crayfish on the littoral macroinvertebrates of large boreal lakes are habitat specific. Freshw. Biol., 59, 12-25.

Sandström A., Andersson M. , Asp A., Bohman P., Edsman L. , Engdahl F., Nyström P., Stenberg M., Hertonsson P., Vrålstad T. and Granèli W, 2014. Population collapses in introduced nonindigenous crayfish. Biol. Invasions, 16, 1961-1977.

Simberloff D. and Gibbons L., 2004. Now you See them, Now you don't! - Population Crashes of Established Introduced Species. Biol. Invasions, 6, 161-172.

Strayer D.L., Eviner V.T., Jeschke J.M. and Pace M.L., 2006. Understanding the long-term effects of species invasions. Trends Ecol. Evol., 21, 645-651.

Thomaz S.M., Agostinho A.A., Gomes L.C., Silveira M.J., Rejmánek M., Aslan C. and Chow E., 2012. Using space-for-time substitution and time sequence approaches in invasion ecology. Freshw. Biol., 57, 2401-2410.

Thomsen M.S., Olden J.D., Wernberg T., Griffin J.N. and Silliman B.R., 2011. A broad framework to organize and compare ecological invasion impacts. Environ. Res., 111, 899-908.

Tolonen K.T., Hämäläinen H., Holopainen I.J. and Karjalainen J., 2001. Influences of habitat type and environmental variables on littoral macroinvertebrate communities in a large lake system. Arch. Hydrobiol., 152, 39-67.

Twardochleb L.A., Olden J.D. and Larson E.R., 2013. A global metaanalysis of the ecological impacts of nonnative crayfish. Freshw. Sci., 32, 1367-1382.

Westman K., Pursiainen M. and Vilkman R., 1979. A new folding trap model which prevents crayfish from escaping. Freshw. Cray., 4, 243-250.

Wilson K.A., Magnuson J.J., Lodge D.M., Hill A.M., Kratz T.K., Perry W.L. and Willis T.V., 2004. A long-term rusty crayfish (Orconectes rusticus) invasion: dispersal patterns and community change in a north temperate lake. Can. Fish. Aquat. Sci., 61, 2255-2266. 


\section{Online Material}


Results of the GLM-analysis between the crayfish, noncrayfish, and introduction site on the Bivalvia, Crustacea, Diptera, Ephemeroptera, Hirunidea, Oligochaeta, and Trichoptera densities in Lake Päijänne from 2007 to 2011.

Bivalvia density differed significantly among study sites ( $p=0.021)$ but with significant interaction between site and time ( $p=0.05)$ (Table 1, Figure3E). Post-hoc analysis of interactions showed that Bivalvia density was higher at the introduction site in 2008 than in other study years $(p=0.002)$ but no other differences were found between sites or years.

Crayfish status and sampling year had a significant effect on Crustacea density (Table 1, Figure 3G), with a significant interaction $(p<0.001)$. Post-hoc analysis of interactions indicated differences between study sites in 2008, 2009, and 2011 (all $p<0.001$ ). In 2008 and 2009 the density was higher at the introduction site than at the crayfish $(p<0.001)$ and noncrayfish sites $(p<0.001)$. However, in 2011 it was higher at the crayfish site than at the two sites with no or few crayfish (both $p=0.004$ ).

Diptera density did not show clear differences between site and sampling time (Table 1), but there was a significant interaction between site and time. Post-hoc comparisons of interactions suggested that in 2011 Diptera density was significantly higher at crayfish site than at non-crayfish and introduction site (both $p<0.001$ ) (Figure 3H).

The mean Ephemeroptera density showed significant variation among study sites and years with a significant interaction $(p<0.001)$ (Table 1). Post-hoc test of interactions indicated difference in density between treatments in $2011(p<0.001)$, and within the introduction site across sampling years. In 2011 Ephemeroptera density was significantly higher at the introduction site than at the crayfish and introduction sites (both $p<0.001$ ) (Figure 3I).

The mean Hirunidea density showed some variation between study sites and years with significant interaction (all $p<0.001$ ) (Table 1). Post-hoc analyses of interactions revealed that at the introduction site the mean Hirunidea density was exceptionally high in 2008 causing differences between crayfish and non-crayfish sites when compared with years 2007, 2009, 2010, and 2011 (all $p<0.001$ ).

The model results indicated that the mean Oligochaeta density differed between sites $(p=0.003)$ and years $(p=$ $0.030)$ (Table 1$)$, but varied among sites and years $(p<0.001$, Figure $3 \mathrm{~K}$ ). Density varied at the introduction site where it was exceptionally high in 2008 being higher than in any other study year (Figure 3K).

The mean Trichoptera density was different among sites and years (Table 1), and with a significant interaction between site and year (Table 1, Figure 3L). Post-hoc comparisons indicated that in some years Trichoptera densities at the introduction site were significantly higher than at the crayfish (between years 2007-2009, 2008-2009, 2009-2010, 2009-2011, all $p<0.001$ ) and non-crayfish sites (between years 2007-2009, 2008-2009, 2009-2010, 2009-2011, all $p<0.001$ ), but no difference was evident between the crayfish and non-crayfish sites in any year. 